\title{
Nullification of citizenship: negotiating authority without identity documents in coastal Odisha, India
}

\begin{abstract}
This paper discusses the case of a community of Bengali immigrant settlers along the coast of Odisha in India at the centre of a unique citizenship controversy. Families have arrived here gradually over the years since 1947, and have generally acquired a range of identity documents from Indian state agencies. These documents certify to a range of rights that signal social and political participation within India: land ownership, voting rights and the receipt of official welfare subsidies. With little warning, a 2005 order by the state government following a high court directive led to the production of a list of 1551 persons, declaring such persons as 'infiltrators'. The list ostensibly comprises those who have entered India illegally after 1971 or born to parents who entered illegally. While no deportation, as originally intended, has taken place, the nullification of their various documents of citizenship has created a void in their lives. This paper examines the wider politics of the case, especially focusing on how those with nullified documents negotiate the authority of the local state and actors within their own society, and what this reveals about the ever contested nature of citizenship in post-partition India.
\end{abstract}

\section{Introduction}

In India, like much of the developing world, citizenship is a beleaguered idea. It is strained by a deep tension between an inclusive and progressive orientation and state attempts to prescribe and bureaucratise the terms of recognition of citizenship, with deeply exclusionary effects. These attempts are not new. Instead, their genesis lies in the birth of this country. The mass movement across nascent borders triggered by the Great Partition of 1947 created a minefield for the issue of legal citizenship. It also created an additional role for the newly formed Indian state to adjudicate claims arising from multiple border crossings. Central to this was the evaluation of 'official documents' held by individuals that had been issued by a plethora of different official agencies by Indian courts and bureaucratic officials in order to determine citizenship. From the very beginning then, 'the relationship between documents and citizenship in post-Partition India inverts the standard expectation that it is the possession of citizenship that enables the acquisition of documents certifying it' (Jayal 2013, 71).

As McConnell (2011) explains, written documents have increasingly served as state technologies of power worldwide. Passports, visas and permit cards regulate and control individuals' legal rights and access to various kinds of power, most centrally movement. Equally, there are both 'emancipatory and repressive' aspects to identity documentation (Caplan and Torpey 2001, 5). In India, from the very beginning, identity documents served as fragile and tenuous signifiers of citizenship, and have been subject to repeated judicial and bureaucratic scrutiny to determine their 'evidentiary value' (Kapur 2010). While in the early years of independence it was visas and permits, as the years went on, these documents were mainly voting cards and ration cards. These were more frequently and easily obtained than passports. Since the 1980 s, courts have repeatedly ruled that 'registration on a voters' list is no proof of citizenship' (Jayal 2013, 72). Ration cards and below poverty line (BPL) cards have been similarly suspect. The rather 'devalued' nature of identity documents in India does not however imply that these are worthless. Quite on the contrary, these are instrumental for the fulfilment of basic needs and livelihoods for an overwhelmingly impoverished population.

The epithet 'documentary citizenship' (Sadiq 2009) captures the immense value of identity documents for immigrants seeking to establish ties with the political community. Much of this value is indeed instrumental, where aspiring citizens seek 'meagre entitlements to subsidised 
food grains, job quotas and entitlement schemes' (Jayal 2013, 99). On their own, they may not carry particular meaning, and the affective dimension, as Jayal puts it, is certainly not always central to the claims that are made for citizenship. However, when denied or questioned, they become imbued with a range of meanings. This is not unlike cases reported elsewhere, like when Gordillo (2006) writes eloquently of how the memory of being deprived of documents for decades in the Argentinean Chaco produced a preoccupation with the materiality of these documents as such.

This paper analyses a peculiar case from the eastern Indian state of Odisha, where citizenship assumed by a community of Bengali immigrants from Bangladesh through years of stay is abruptly questioned by an unexpected state order. In 2005, the state government following a High Court directive produced a list mentioning the names of 1551 persons, who have ostensibly entered India 'illegally' after 1971, or born to parents who entered illegally. As will be discussed in the next section, 1971 was the date retrospectively imposed by the Indian state through amendments to the 1955 Citizenship Act in 1985, as the deadline for refugees to enter from the eastern border. Needless to add, many thousands of Bengalis have come to India since then, to escape gruesome violence post the creation of Bangladesh. The people on this list are labelled in Odiya as anuprabeshkari, translated into English as 'infiltrator'. So many years after, it has taken people by surprise and caused much anguish. It is hard to distinguish between those who came before 1971 and after, as identification largely depends on nebulous oral accounts and hearsay. The list itself is questionable and ridden with anomalies, but wherever people have been 'identified', their official documents have been declared void and their names have been struck off the electoral register and BPL lists. No deportation, as originally intended, has taken place, but their lives are in suspension without any legally valid documents.

In this paper, I am concerned with those peoples for whom uncertain citizenship status in a formal legal sense continues to be a struggle. Jayal has rightly criticised their neglect within political theory 'on the assumption that citizenship-as-legal status is a settled issue' $(2013,84)$. Also referred to as 'thin citizenship', it often receives less attention as compared to issues of 'thick citizenship', which is about 'a more active conception of citizenship as belonging and identity and also as performance' (Kymlicka and Norman 1995 as cited in Jayal 2013, 297). But where does this leave cases like the one at the heart of this paper, as others concerning 'aliens, migrants, refugees and asylum seekers' (Jayal 2013, 84) who may be physically present within a nation-state but their legal status is contested? And what does it mean for their substantive experience of citizenship (aka Holston 2008)?

In fact, this paper considers the creation of a new analytical category of 'infiltrators', who find themselves in the extremely unusual situation of having obtained official recognition (even if not legal status, as the latter was never ascertained) through the steady accumulation of identity documents over time, and then having to lose it due to retrospective state legislation and an unprecedented bureaucratic order. Both identity documents and the effects of such state action (dubbed as 'state effects' following Mitchell 1999, whereby a single act of the state elicits multiple social practices) play a key part in this story. My paper examines the wider politics of the case through which ordinary life is upturned and renegotiated from an uncertain legal but also social and moral point of view. Its purpose is to show how the binary between formal (as legal) and substantive (in the sense of belonging, identity and access to state services) citizenship is a tenuous one (see also Jayal 2013, Holston 2008 for related debates), and that 
the need for securing the former in order to access the latter is a very real one for many around the world.

The paper draws on four weeks of intensive qualitative research in the predominantly Bengali villages of Ambapalli and Narayanpur villages ${ }^{1}$ in Mahakalpada block of Kendrapara district in November 2012. Accompanied by a field assistant, I conducted long interviews with approximately 15 households in the predominantly Bengali villages of Ambapalli and Narayanpur besides 10 key informants- past or serving local functionaries like sarpanch, revenue inspectors and dealers- who were both Bengali and Odiya. I also conducted two focus group discussions, one in each village. It was difficult to identify households that belonged to the list, contributing to a slow pace of investigation. Given the extremely sensitive nature of the subject, I took care never to identify any of my respondents to any officials being interviewed, or vice versa. I also spent a lot of time listening to peoples' narratives, respecting that talking to me was a cathartic experience for them, especially as I was apparently the first outsider to actually visit these villages to find out more in a long time. As I am fluent in Odiya, I was effective in understanding the nuances of their accounts.

\section{Of citizenship and inclusion}

The question of citizenship as one of inclusion within the political community necessarily engages the sovereign power of the state. In their account of the emergence of the concept of sovereignty, Hansen and Sepputat (2005) argue that a distinction must be made between the aspiration to sovereignty (the idea of a 'normal sovereign state' with de facto control over its populations and territories) and the much more concrete practices of authority dispersed throughout the territory. And therefore, to understand how sovereign power actually works in the present day, we need to observe the modes through which sovereign power is most vividly expressed. The inscription of 'sovereign violence' on people, their bodies and 'bare' lives is most relevant here. Agamben (1998) describes the classification of some people as undeserving of the most basic reach of dignity and humanity and their exclusion from the political community while remaining 'internal to society and the economy' (like women, slaves, outcasts in Roman times) as the most elementary operation of sovereign power (as cited in Hansen and Sepputat 2005, 16). Agamben's work (1998) focused on a 'boundless state of exception' where sovereign power could split the political community along different axes of membership and inclusion (as cited in Das and Poole 2004, 12). Clearly, these ideas have strong resonance even today in the form of refugees, migrants and asylum seekers all over the world.

Interpreting this further, Das and Poole (2004) argue that such 'states of exception' are not confined to particular spaces or time periods only, but rather are in everyday practices that are both 'simultaneously inside and outside the law' $(2004,15)$. Akhil Gupta further points out that Agamben's theory of the 'state of exception' is not very persuasive in the Indian context because it hinges upon a 'strong theory of sovereignty and a powerfully unified state apparatus', while the Indian state is 'multicentred, multileveled and decentralised' $(2012,17$ 18). Gupta's own work is not about extreme violence in a state of exception, but rather the perpetuation of daily violence through the denial of food, clothing, shelter and healthcare to the needy. Besides, India presents the paradoxical situation the poor being the repository of popular sovereignty and yet their horrific poverty is normalised into public discourse. 
What this means for the case at hand is that while there are important differences between refugees and migrants who lack formal citizenship status, and the large numbers of poor people including minorities like adivasis and sufferers of communal violence that are internally displaced, there are also similarities and continuities in their systemic oppression. Nevertheless, this paper is focused on the citizenship struggles of those lacking formal status, in an attempt also to pin down those elements that are distinctive.

\section{The restrictive politics of citizenship in India}

Any consideration of citizenship and citizenship politics in India must start at the Partition, the discussions leading up to the constitutional settlement and the constitution itself. Various scholars have argued that elements of jus sanguinis were present from the start despite the formal pledge to a jus soli conception of citizenship (Jayal 2013; Rodrigues 2008; Sadiq 2009). Jayal's authoritative work, in particular, shows that despite the constitutional endorsement of a secular jus soli conception of citizenship, the 'idea of the natural citizen' remained 'Hindu and male' $(2013,53)$. This bias gradually made its way into statutory law through later aggravating developments like illegal immigration from Bangladesh and to a lesser extent, on the western side from Pakistan as well. Moreover, the politics of religious identity has consistently remained at the centre of these debates and developments. The constitutional debates informing Articles 6 and 7 labelled Hindus fleeing the communal violence and their homes in Pakistan as refugees, whereas Muslims from India similarly escaping anarchy were called migrants. The constructed binary between 'political refugees' versus 'economic migrants' found uncomfortable echoes in contemporary international refugee law, but in India, it absolutely served to conceal religious identities, so that Muslims could be typecast as 'opportunistic migrants' whose loyalties lay with Pakistan (Jayal 2013, 59).

While the western border between India and Pakistan caused much concern in those early years, in-migration of both Hindu and Muslim refugees, first from East Pakistan, and then, following the conflict of 1971, from the new state of Bangladesh led to anxieties over citizenship in more recent decades. In fact, it was when the scale of particularly Muslim immigration began to upset the demographic balance between Hindus and Muslims in the eastern state of Assam that the government moved towards a more restrictive regime (Jayal 2013, 63). In 1985, the Citizenship Act of 1955 was crucially amended with the addition of Article 6A. This excluded persons born in India from Indian citizenship 'whose father possessed immunity from suits and legal processes accorded to an envoy of foreign power and is not a citizen of India, and whose father is an enemy alien and the birth occurs in a place under enemy occupation' (Rodrigues $2008,169)^{2}$. This amendment had the effect of inserting an ethnic belonging qualification to the basic principle of citizenship by birth or jus soli, with profoundly exclusionary implications, especially with respect to people associated with Pakistan and later, Bangladesh. Successive amendments to the Citizenship Act continued in this vein.

Moreover, in 1985, the Citizenship Act of 1955 that classified the various sources of citizenship in India was amended specifically to cope with in-migration from Bangladesh. The continuous flows of people from Bangladesh after 1971 led to a massive student-led political agitation from 1979-85 in particularly affected states like Assam. This resulted in the Assam Accord, a political agreement with the central government, according to which: a) all those who had migrated between 1966 could stay as citizens; b) those who had migrated between 1966-1971 
could stay provided they had themselves registered as citizens; and c) all those who migrated thereafter were simply illegal immigrants (Jayal 2013: 64) $)^{3}$.

In the following years, the issue of immigration became an emotive issue for most Indians. A rising majoritarian sentiment led to widespread anger, directed especially at some political parties for using illegal immigrants as 'vote banks' and easing their stay with the facilitation of identity documents like ration cards and election cards. Further restrictions followed. In 2003, an amendment to the 1955 Act modified the provision of citizenship by birth to exclude from it such persons born in India as have one parent who is an illegal immigrant at the time of their birth (Article 3c ii) ${ }^{4}$.

These developments were unfavourable for India's refugee population to say the least. India has neither ratified the 1951 Convention on the Status of Refugees nor the 1967 protocol, which means that refugees in India have no access to the provisions of international humanitarian law (McConnell 2011). India's ratification of the International Covenant on Civil and Political Rights (ICPPR), as well as the Covenant on Economic, Social and Cultural Rights does however place the country under an obligation to accord equal treatment to citizens and noncitizens wherever possible; though India has put in a reservation to the ICPPR, reserving its right to implement its law on foreigners.

The origins of this case lay in the disastrous rehabilitation policy of the government of India since 1947, both at the centre and in West Bengal that focused on trying to disperse refugees away from those precise areas where they chose to concentrate (Chatterji 2007, 132-3). Taking the view that there was simply not enough land in West Bengal to accommodate all the arrivals, the government of West Bengal tried to cajole other states to take them in and house them in large camps and colonies, "usually in barren or "jungly" places where the refugees had no wish to go' (ibid.). It is no surprise that this enterprise was not a success since refugees simply ran away, either back to Calcutta or other towns in Bengal.

Many thousand Hindus were steadily crossing into West Bengal, following the Noakhali and Tippera riots of 1946 and the Khulna riots of 1960, and then nearly two million left after holy Muslim relics were stolen from the Hazratbal shrine in Kashmir in 1964 and Hindus in East Pakistan feared a backlash (Chatterji 2007). Many of them were extremely poor and of low castes, with few assets or connections, and had therefore been amongst the last to leave east Bengal, only when they 'were driven out by extreme violence or intolerable hardship' (Chatterji 2007, 118). Following this turning point, the central and state governments designated 200,000 acres of 'waste land' and forests in a number of different states- Bihar, Uttar Pradesh, Madhya Pradesh and Rajasthan- and established 38 refugee colonies in these spaces. Of these, 'Dandakaranya'- spread over nearly 30000 square miles of barren and waste scrubland in Bihar, Odisha and Madhya Pradesh- was the most 'ambitious and controversial' (Chatterji 2007, 136). It is these inhospitable environs that many refugees abandoned, and then found their way to other places (Kudaisya 1997). Coastal Odisha was appealing given the similarity in its physical habitat with East Bengal. The refugee exodus away from these camps is one of the most important points at which this story begins.

\section{Refugees and immigrants in coastal Odisha: a brief history of arrival}


Generally, the 'refugee' is the iconic symbol of all that is exclusionary about the construction of statehood and contemporary political identity (McConnell 2011, Isin 2008). The history of modern South Asia following the partition of 1947 richly establishes that such citizen-refugee labels are political, serving the agendas, interests and ideologies of particular regimes. In the unique events of this story, the term 'refugee' oddly became a safe haven for those who could claim it. And in fact, the 2005 order by the state government effectively created an even inferior political denominator, the anuprabeshkari or 'infiltrator'.

In this section, I will try to briefly summarise the historical context to the arrival of Bengalis from West and East Bengal into these tracts of coastal Odisha, particularly the Rajnagar and Mahakalpada blocks of Kendrapara district. Although heavily populated now, these lands were largely unoccupied in previous decades around independence. Much of this space is still densely forested, and falls within the Bhitarkanika National Park and Wildlife Sanctuary (which was later notified in 1975). Oral histories collected in the two case villages of Ambapalli and Narayanpur reveal that in British times, these areas came within the Kujang estate of the Odiya king Vardhaman. With the abolition of zamindari (a land revenue system) in Odisha in $1952^{5}$, the King announced the availability of fertile unoccupied land in coastal tracts in newspapers, which then led to many Bengalis from West Bengal coming to take up residence here. They initially took land on lease from the king, but then received titles on their lands in a settlement exercise by the state government in 1965. These can be called the 'first wave' of Bengali settlers here, all of whom have land pattas or title records for their plots. During these early years, there were only three main revenue villages in these parts. These were all Odiya villages and situated inland, while the coastal tracts remained uninhabited.

Between the late 1940s and 1970s however, circumstances changed gradually but definitively as other groups of people referred to as 'refugees' arrived to live here. My interviews suggested a general acceptance that in these decades- the 1950s to the 1970s- the Bengalis who came to Odisha were from East Bengal. Moreover, they were received by the state government, land was cleared for them and they were provided other forms of assistance to settle down. For all those who now live in these coastal villages, these people who arrived from East Bengal were legitimately given refuge by the state. As more people came, new settlements grew, and now entire villages are colloquially referred to as 'refugee villages' or 'refugee colonies', even though their residents are formally Indian citizens.

These oral narratives broadly resonate with the story told by historians like Joya Chatterji (2007, 2012) who have studied partition and migration on India's eastern border intensively. As I have discussed in the previous section, support was provided by the central and state governments, although it was chaotic and coloured by cynical political games that generally involved 'batting' refugees away as much as possible. Today's villages in Kendrapara district in coastal Odisha have thousands of Bengali families whose circumstances are different. 'Not everyone's story is the same', said one man, but there is a unifying element of compulsion behind each one. Perhaps most importantly, these include families whose stories do not necessarily end with arrival before December 1971, the date retrospectively imposed by the Indian state in 1985 in order for refugees to qualify for citizenship.

Typically, all these Bengali families are from lower caste groups like namasudras and debnath, in line with the account presented by Chatterji (2007). In my analysis of the 15 households that I interviewed, I found at least three types of scenarios. The first and largest group comprised 
those whose parents or grandparents had come to various districts in West Bengal such as 24 Parganas, Midnapore, Sealdah and Nadia in the 1950s, and then went to refugee camps across India before finding their way here. This group included people who had left the camp in Dandakaranya and Malkangiri (in western Odisha) and come to another camp in Charbatia in coastal Odisha, where they had been given help by the state government ${ }^{6}$. So these men and women were either born in West Bengal or in these very villages in Odisha. Second, those whose parents or grandparents had come to West Bengal in the 1950s or 1960s, but who had not attended a relief camp, and with the help of relatives and other acquaintances had made their way to Odisha in search of work. The port city of Paradip was a popular destination, and many people went there, but left as it became too crowded. Following social networks, they too came to these coastal areas given the ample space, proximity to forest, rivers and the sea, and the possibilities of a new life these contained. Third, those who came to India, typically Kolkata in the early 1990s, trying to escape the unrest in Bangladesh following the demolition of the Babri Masjid in December 1992. They too followed the leads of other relatives who had arrived in India in previous decades and them to coastal Odisha. One or two households that I spoke to came to India from Bangladesh much more recently, i.e., in 2002-3. I did not meet or hear of anyone who has come to these villages from Bangladesh any later than that in course of my four weeks of fieldwork.

Early reactions from the local Odiya population to their Bengali visitors were not favourable. One woman said, 'initially, when we came and started clearing the place to live, the Odiya people would come from the surrounding fields and would snatch our spades and shovels...they let their cattle into our fields and created trouble for us in many ways'. Many of the earlier settlements were inland, and as more people arrived, there was a gradual movement much closer to the sea. As Bengalis from East Bengal began fishing in the rivers and estuaries, they came into conflict with Odiya fishing castes who claimed customary rights on these waters, leading also to a court petition and eventually the forging of an informal agreement between Odiyas and Bengali fishers (Chhotray 2016).

So while it is certainly no secret that many Bengalis in coastal Odisha migrated here from Bangladesh, the passing years have granted a regularity to life and a settling down of sorts. Lands were bought, houses built, farms cultivated and most importantly, documents of belonging to the Indian state were acquired. Every family I interviewed is on the voter list and has a ration card, and most possessed BPL cards as well. Generally these documents were acquired in the 1990s. Most also had some form of written registration document for their land plots (though not necessarily a formal land deed or patta), and paid both taxes and penalties (for land encroached upon; this seemed to be fairly widespread). They both voted in and contested elections. For all practical purposes, they had become Indian citizens.

All this came to an abrupt halt one January in 2005, when a local Revenue Inspector accompanied by the police arrived in these villages to notify approximately 25 families in each that they had been identified as Bangladeshi nationals and were given 30 days to leave the country. The 'quit India' notice (officially referred to as such) had been issued by the Kendrapara district collectorate. There was no explanation offered and the notices were in English not Odiya, the local language, producing further incomprehension.. While the written order did not contain the term 'infiltrator' (anuprabeshkari in Odiya), this is the term that was used by the state in its oral explanations and other accompanying written communication. 


\section{State effects: production of the list and construction of 'infiltrator'}

In the persuasive scholarship on the everyday state in India, the state is 'studied anthropologically', and not as a 'discrete or singular' entity (Corbridge et al 2005, 5-6). 'Quotidian practices of rule' or the everyday conduct of junior state officials constitute the state that poor people see, and such 'sightings' are far from being 'straightforward or unitary' (ibid.). It is in this vein that Ferguson and Gupta elaborate, 'states are not simply functional bureaucratic apparatuses, but powerful sites of symbolic and cultural production that are themselves always culturally represented and understood' (2002, 981). Further, Mitchell (1999) has usefully argued that the boundary of the 'state system never marks a 'real exterior', and instead it is through the vast network of institutional mechanisms that social and political order is maintained and a 'line drawn between state and society' $(1999,175)$. This, he explains, is only an appearance of an autonomous state that is separate from society, a 'state effect', where the point is not so much to try and distinguish the 'real' from the 'illusory' as much as it is understand the multiple practices that produce this effect (ibid.).

The issuing of such a notice, apparently out of the blue, and what ensued afterwards demonstrate well what Mitchell (1999) has persuasively described as the 'structural effect' of the state, where the state acquires a magnified presence precisely through acts such as these. For the Bengali communities in these parts, their interactions with the state so far had been primarily routine, getting PDS supplies, registering their land plots and paying land taxes. If anything, the state appeared benevolent in at least some of these transactions, and even when there were corrupt acts or arbitrary behaviour by local officials like the RI or the tehsildar, then they were not being singled out. With the state declaration of them as 'infiltrators', who were certainly non-citizens and even non-refugees, the state appeared proximate and menacing in a way it had previously not. Even though the national politics of citizenship had been moving in a restrictive direction culminating in that 2003 amendment to the 1955 Citizenship Act, these matters had not really caused any concern to people here until this notice, because the state government had not taken any action.

With its strong connotation of physical intrusion, the term 'infiltrator' did not make any sense to people who had been living in these areas for years, if not decades. There was mass incomprehension and bewilderment, of exactly what this meant, how it had come about and what would happen next. In my conversations with people, both those on the list and not, what emerged was a remarkable mimetic memory of state procedures. Instead of rejecting out right the entire development as fraudulent or improbable, given the general calm and stability of their lives since they arrived, they relived the entire episode with details of their responses at critical points. A single act of the state issuing the list translated into multiple social practices, which greatly accentuated the effect of that act in the first place.

In the early days after the notice had been issued, people struggled to piece together an explanation of what could have motivated it. The thought that they had been targeted 'despite being Hindu' was uppermost in many minds. One ex-Sarpanch went as far as to say, 'Maybe the central government wanted to list the Muslim people who came to India after 1971, but the central government got it wrong'. In this respect, an interesting parallel can be drawn with the case of Hindu migrants from Pakistan into border districts in the western state of Rajasthan discussed by Jayal (2013). Here circumstances unfolded differently with ration cards being distributed at state organised citizenship camps back in 1972, and then later in 2005, though 
not everyone received a ration card. Despite this state recognition, Jayal documents that they were widely disparaged for being 'Pakistani', much like the immigrants in this case who were looked down upon for being Bangladeshi infiltrators, after the notice had been issued. Being Hindu meant that 'religious identity has little purchase in an environment populated by coreligionists... and it is the markers of difference that count for more' $(2013,93)$.

No one I interviewed in the two villages had any clear idea of what had caused the state to take such action at this point or how the list had been arrived at. No open enumeration or checking of documents had ever been carried out by state officials in advance of the notice being issued. The ex-sarpanch of the local Ramnagar panchayat observed astutely that there are many more than 1551 persons who had come to these parts from Bangladesh after 1971, and it was not really possible to know who they were or how many. He recalled that some people from Ambapalli village had gone to the Collector's office days before the notice with proceeds of collections towards the 2004 earthquake in Latur, and had come back with tales of how the state was preparing to evict 'Bangladeshi people' from these parts. The notice had followed days after, but he too confirmed that the state had not carried out any enumeration.

I interviewed the district authorities to find out more. The District Collector of Kendrapara, who was new to the post, simply restated that 'infiltrators came into this area without the prior permission of the competent authorities'. They were not comfortable or willing to divulge the precise antecedents of this order, and it was impossible to trace the previous Collector who had been in post at the time. The closest explanation could be that there had been a petition to the High Court in the wake of the 2003 amendment to the Citizenship Act, leading to a court directive that the state government then acted upon ${ }^{7}$. The Additional Tehsildar, the land records official, who had in fact been in post at the time stated that the list had followed a 'proper' enquiry and the checking of documents, and only those who could not furnish any 'proof of arrival' prior to 1971 or evidence of social relationships had been placed in the list. As for issues like apparent anomalies on the list (one brother mentioned, the other not), he simply did not respond. He also refrained from showing us any concrete proof of the survey itself.

During my fieldwork, more details emerged of how the affected people had in fact volunteered themselves to have all their documents 'checked'. One man in Ambapalli said, 'No, they never asked for documents. Even when we tried to show our documents, they were simply not interested.' In another man's words, 'We even went to the Collector's office to make enquiries.... but nobody came'. These voices confirm what has been repeatedly identified in the wider scholarship on how material documents gain in significance, especially when their holders have been 'denied' these in the past (see Gordillo 2006). But the unusualness of this case is that their holders actually obtained their assorted documents with relative ease, as already discussed, and now, in their prospective nullification, were these becoming valuable.

Gordillo (2006) has also written of the 'ad hoc' nature of documents that end up becoming revered or even fetishized. In this case, the affected persons would not have managed to convince the officials of their eligibility to qualify as Indian citizens even if proper 'checking' had in fact taken place. Their assorted papers, typically held carefully in little plastic bags, including ration cards, voter identity cards and BPL cards, were all acquired in the 1990s and would not count as proof of their arrival here before 1971. Several people also spoke of having lost their documents in the super-cyclone of 1999. One woman poignantly said, 'we are 
illiterate, how would we have known the importance of documents?' Only in one of the 15 households I spoke to did I hear of the 'relief eligibility certificate', a document that was apparently given to refugees joining relief camps in the 1960s But as I heard, the chaos of camps and the dissimilitude of circumstances meant that not everyone who stayed in a camp still had this certificate. One man recalled that his father, like others, had 'returned these cards' to the authorities when Bangladesh became independent, thinking they might return but then changed their mind and stayed on. For most though, this 'relief eligibility certificate' was only a notion, they had never seen or owned one.

Another detail that emerged upon probing is that for two years after 2005, the year the notice was issued, there was no further action. The state appeared, threatened the worst, and then quite erratically, nothing happened. This suspense was almost more disconcerting than the actual consequences. One woman said, 'for months I could not sleep...every time I heard the sound of a vehicle going by, I would be crippled by anxiety that they are here to take us away'. In 2007, a Bengali school teacher from a neighbouring village was tasked with a 'verification exercise', together with the local Tehsildar and a policeman. Some people remembered this exercise, and confirmed that it was after 2007 that their names were 'struck off' the PDS list and they stopped getting rations from the dealer. This was perhaps the first material consequence of nullification of citizenship. There were others, and I return to these in the penultimate section.

One theme that repeatedly came up was of how the list actually came about. Many people were convinced that somebody with local knowledge had supplied names randomly to the block office in private. 'How else would the state know these names, even of small children?', said one respondent. There is a strong desire to mete out direct punishment, like through a good beating, to the 'informer' if he/she were ever caught out. More than seven years on (at the time of fieldwork), this was looking harder. Many people thought that local party politics must have produced informers trying to get back at the rival party, but nobody had any specific clues or further explanation. Apart from those whose lives have been irreversibly altered due to this list, others in and around the village as well as the state administration that issued this stern order, are inclined to forget about the episode. 'The matter has gone cold', said the ex-sarpanch.

Das and Poole write that documents 'bear the double sign of the state's distance and its penetration into the life of the everyday' $(2004,15)$. Das also writes that the 'documentary practices of the state and the utterances that embody it acquire a life in the practice of the community' $(2004,234)$. These are observable in these case villages even today, when people of the same community, with the same backgrounds and histories, are even categorising themselves according to this official timeline imposed retrospectively by the state. They talk about who came later and why he or she is not on the list. This self-classification amounts to the local buying-in of this state intervention, the consequences of which are being felt long after 2005 , both in the form of material disadvantage as well as social rebuke. I'll return to that shortly.

\section{Resistance and local mobilisation}

It is worth discussing the brief resistance and local mobilisation that ensued against this unexpected order. This is not as much to gauge their effectiveness in producing any tangible results, but rather to acknowledge the range of social reactions elicited by the state. 
In the initial period following the notice however, there was solidarity amongst Bengalis in the concerned villages to stand together with those who were on the list. Heated discussions were held in many meetings, letters were written to the Human Rights Commission. Many Odiyas also supported these efforts. A united Bengali-Odiya front formalised into a body called the Utkal Banga Suraksha Samiti (translated as 'Odisha-Bengal Security Committee) or UBSS that organised demonstrations, threatened road blockades in the event of police action and facilitated political attention into this issue. A number of regional politicians from different political parties made a representation to the then Union Home Minister (Congress leader Shivraj Patil) and to the leader of the Congress party, Sonia Gandhi.

Some families decided to take the legal route. In this regard, the ex-sarpanch said, 'Well some people wanted to go to the High Court against the verdict. But I suggested to them not to do so. Because when the matter goes to the High Court, the Court will look at the citizenship status and not give its verdict on humanitarian grounds. I told them only to go if they had authentic documents which could justify the citizenship status.' In the end, according to a local lawyer, only a handful of 18 families appealed to the High Court, but the vast majority did not feel confident of actually having their documents examined in a court of law. The state and its institutions appeared to be larger than life, and their documents - materially unchangedseemed to fall short of the worth necessary for its recognition.

Even though the order had threatened deportation, never was any action taken by the state to actually deport these individuals. This would have required sustained and effective coordination by the state machinery, which was demonstrably missing, as I argue further in the next section. But equally, there was no real social or political demand from any quarters for deportation either. This could be because the Bengali communities in coastal Odisha did not constitute any meaningful challenge to the local Odiya population, which was predominantly upper caste. This is in contrast to the sharp friction between Bengali immigrants and local Odiya scheduled tribes as reported by Ambagudia (2014) in western Odisha.

There was an attempt to scale up the activities of UBSS into a larger body that would deal with the concerns of Bengali immigrants anywhere in India. A body called the Nikhil Bharat Udbastu Bengali Samanwaya Samiti (All India Displaced Bengalis' Coordination Committee) was established in 2005 with branches in a few places across India, aiming to improve awareness of their 'rights' amongst the Bengali immigrant population in India, and to provide political support. At the time of fieldwork in 2012, I was not able to establish that any of the affected persons had any idea about this initiative. Even as they escaped deportation, those labelled as 'infiltrators' and their families have continued to live, negotiating the state as infiltrators.

\section{Negotiating authority as infiltrators}

In this penultimate section, I will take a close look at the impact that the nullification of citizenship has had on the lives of those identified as infiltrators. The question of how persons labelled as 'infiltrators' negotiate authority would mark an addition to the broader scholarship on how the poor access the state in India, albeit by highlighting the special circumstances of those without formal citizenship, i.e., refugees and immigrants. Partha Chatterjee's iconic work famously declaring that 'most of the inhabitants of India are only tenuously, and even then ambiguously and contextually, rights bearing citizens in the sense imagined by the 
Constitution' $(2004,38)$. While this is certainly the case, their very existence as Indian citizens is not in doubt, and as Chatterjee persuasively shows in his study of squatters in Calcutta, they are able to collectively mobilise and win state benefits, though as members of a 'political society' and not 'civil society. Core to this endeavour is their constitution of themselves as a 'population group' worthy of receiving support from a state that is interested in their wellbeing, aka governmentality. This was not the case with the 'infiltrators' in this study, and perhaps not so with refugee groups more generally. To borrow Jayal's words, the 'moral bases' of the claims of infiltrators are somehow substantively different.

My account brings into sharp relief the sheer arbitrariness of the terms of exclusion which unfolded. The imperfect calibrations of state implementation of its own order thus fully revealed the multi-sited and often incoherent state apparatus that exists in India (Gupta 2012). I will examine the negotiations that unfolded in the following areas: access to state welfare programmes that involved transfer of subsidies or benefits based on a list, access to state facilities (like schooling or heath centres) that are not based on a list, payment of taxes for land, voting and participation in wage work. Finally, I will also briefly consider the struggles being encountered by affected Bengalis while attempting to fish in local rivers.

Perhaps the most visible change as a result of the list coming into effect is the cancellation of the names of 'infiltrators' from the PDS list used by the dealer to give subsidised rations like rice or kerosene to beneficiaries. This too did not happen until 2007, which is being associated with the local verification exercise mentioned previously. All my informants confirmed that they no longer received supplies. However, in private, a few did admit they received some things from the PDS dealer, even if less than their usual share. It emerged that the Bengali Sarpanch had requested the PDS dealer to give one litre of kerosene to each affected household on a compassionate basis, especially because this was a cyclone prone region and households could be out of fuel at any time. The ease of striking off names from a list meant that similar experiences were observed with other state list-based or targeted welfare programmes. People getting money from the housing assistance programme (Indira Awas Yojana) also reported not receiving the later instalments. A few elderly people reported suspension of their old age pensions.

Where state assistance did not take the form of measured individual benefits, like a state school or health care (Anganwadi) centre, the experiences were vastly different. People identified as infiltrators continued to use these facilities without any difficulty. However, certification for school leaving was becoming an issue, and many students were denied these by the Revenue Inspector as their names were on the list. People found ingenious ways to deal with this situation. As one man explained, 'A student needs a residence certificate, which is issued from the RI's office. So we are asking families to buy 10 decimals of agricultural land and get it registered. Once the registration is done, we ask them to apply for a conversion to at least one decimal of homestead land, paying a small penalty. Once these two registrations are done, the process of getting a residence certificate becomes easier.' When I asked if the RI did not query about these applicants being on the list, then they simply said that they paid him a small sum for his help. The RI for his part blamed people for attempting to forge their way out of the situation, even mentioning a case of two men who were trying to forge their names on the application by changing their names on the voters' list. 
There is the related problem of payment of land tax. In principle, those on the list should no longer be paying these, but in reality, I found a wide range of practices. One man said, 'many times, I have urged the RI and Tehsildar to collect taxes from me, even showing them my documents, but they refused saying my name is on the list'. But another woman said, 'The government has restricted us assistance through the PDS but it is collecting tax from us. Isn't it strange? And moreover, we are paying more and getting receipt for less'. The practices of voting were even more complicated. Despite 'infiltrators' being struck off the voting lists, I actually found that many people continued to cast their voters. In Narayanpur, I was told that people on the list have carried on voting in panchayat elections due to an 'understanding' amongst the ward members as there were only two main political parties. But in Ambapalli, I also spoke to households that report being denied the right to vote.

Amidst this confusing and uneven landscape of the extent of exclusion, one thing is clear. People have continued to access state facilities in some areas. A few households even reported getting work on the national rural employment guarantee programme (NREGS). This suggests that while some identity documents like ration cards and BPL cards have been easier to nullify, others like voting cards and NREGS job cards have not been equally stringently scrutinised, and seem to be more open to local management. The reasons for this variation are not immediately clear, though it could be down to the fact that ration cards and BPL cards are tied in with the provision of finite state resources which are targeted to particular beneficiaries, whereas voting cards and NREGS job cards are not. They depend on seemingly unlimited votes and manual labour that a large population group can offer, albeit in exchange of payment (in the case of NREGS). Local officials are also incentivised to expand the numbers of registered voters and job card holders for NREGS. It also means that the state's 'systems' are not efficient enough for cancellation on one list to automatically translate into another, though this may well change in the future with the introduction of biometric techniques. People are still able to find wage work, both a few hours away (like in Paradip) and in distant locations like in Adaman and Nicobar, where the usual practices of hiring informal casual labour do not require identity documents.

The citizenship controversy also seemed to have impacted their tussles with powerful social actors, besides government functionaries. Many Bengalis practise inland fishing on the rivers and estuaries and have come into conflict with Odiya fishing caste groups that claim exclusive customary rights on these. The anuprabeskhari controversy has also undermined the position of Bengalis in negotiating the local vigilantism practised by these caste groups (Chhotray, 2016). During my fieldwork, a Bengali man from Ambapalli (not on the list himself) was openly slapped by aggressive Odiya kaibarta (caste fishermen) men, challenging the fees being levied by these caste groups for fishing on inland rivers.

Even as people affected by this state order negotiate the more material aspects of their absurd situation through a combination of stoic acceptance and wily manoeuvring, it is the social humiliation that constitutes the most enduring and hurtful of effects. People tagged as infiltrators also had to suffer loud, wayward remarks in public about how they should not be given any state help. When other Bengalis in their village say such things, it hurts more. As one said, 'The only difference between us and them is that they came earlier, and we came later'. Another said, 'We cannot demand anything and we feel isolated. If a person is continuously accused of stealing for no reason, then you can imagine how that person will feel. Most of us have proper documents and still we are not being recognised as the citizens of India'. 
A retired sarpanch summed up the situation well, that although people on this list and their families continue to live here, the whole incident has damaged any sense of entitlement that they may have had. The matter has largely receded from the state's attention, but their problem remains unsolved, and they have had to adopt an attitude of servility, doing menial jobs for others with no or little pay besides enduring orders and rough talk.

\section{Conclusion}

The case discussed in this paper offers to deepen our understanding of the struggles being faced by those whose formal citizenship status is in doubt. In response to Jayal's (2013) call for questioning the sometimes unhelpful compartmentalisation between thin (as legal status) and thick (as more substantive access and belonging) citizenship, this case provides further insight into how problems with the first resolutely impact upon the second. Moreover, it shows that questions relating to the first are more alive than ever. It brings into focus the critical role played by identity documents in mediating this continuum between thin and thick citizenship.

The unusual story narrated here also presents us with a new analytical category of 'infiltrator' who, in the Indian context, lacks even the tenuous respectability of a 'legitimate refugee'. It is a darker version of the more commonly termed 'illegal immigrant', at the core of which is the notion of their unsanctioned presence under the cover of various state certifications, which have been expediently granted and improperly acquired. Cancellation of identity documents obtained through years of stay and fairly 'regular' interactions with local state officials, as is common for immigrants and refugees in India, is thus seen as a rational- if unprecedentedreaction by the state, with devastating effects. While many poor people in India, especially from disadvantaged groups like adivasis and Dalits, regularly suffer the effects of arbitrary and oppressive state action, it is worth highlighting the distinctive nature of the struggles assailing immigrants and refugees. This paper has shown that their claims are easily dislodged, without the certainty of constitutionally and socially recognised rights and entitlements.

The case has allowed us an opportunity to revisit the literature relating to the exercise of sovereign state power through the classification of people, depending on their deservedness of belonging to a political community. These practices, profoundly exclusionary in scope, concern the vast numbers of refugees, migrants and asylum seekers all over the world. The paper shows why the production of this list of 1551 infiltrators in 2005, while unusual, is not exceptional, and merits to be viewed in the larger context of the restrictive politics of citizenship that have unfolded in India since the partition itself ${ }^{8}$.

The paper also illustrates that exclusion does not require physical borders, or indeed that the margins of the state necessarily need to be physically remote somehow (Das and Poole 2004). It contributes to the wider understanding of a border that is 'both conceptual and territorial' and is a 'privileged site' for eliciting certain kinds of practices (Fearme 2004, 90). The paper argues that exclusion rests on state acts, which reverberate in the form of effects that are magnified throughout the social realm, making the state and its reach seem larger (Mitchell 1999). It contains much detail of this phenomenon, beginning from the ways in which the term anuprabeshkari/infiltrator are internalised within this community, to the manner in which those impacted are left with an uncertain vocabulary for self-identification as well as moral status to continue negotiating authority to access the state, and right down to the terms on which the list is resisted. It affirms the valuable role of identity documents in serving as an instrument of state 
power. For those affected, the case also shows how their nullification serves the curious purpose of rendering them valuable and useless at the same time.

Finally, the paper also describes the more nuanced character of actual material deprivation as a result of this list, which is not absolute, revealing the incoherent nature of the state machinery itself. And yet, the profoundly degrading social effects that have ensued show that the true consequence of the nullification of identity documents has been to undermine their social status as citizens.

\section{References}

Agamben, G. 1998. Homo Sacer: Sovereign Power and Bare Life. Translated by D. HellerRoazen. Stanford, CA: Stanford University Press.

Ambagudia, J. 2014. 'Dissent, conflict and rights: Migration and the politics of citizenship in India'. Paper presented at the European Association of South Asian Studies, Zurich.

Baxi, Upendra. 2010. 'Caste, Census and Constitutional Justice.' Economic and Political Weekly 45 (37): 25-29.

Caplan, J, and Torpey, J. 2001. 'Introduction' in Documenting Individual Identity: The Development of State Practices in the Modern World edited by Caplan, J. and Torpey, J., 112. Princeton: Princeton University Press.

Chatterjee, P. 2004. The Politics of the Governed: Reflections on Popular Politics in most of the world. New York: Columbia University Press.

Chatterji, Joya. 2007. The Spoils of Partition: Bengal and India, 1947-67. Cambridge Studies in Indian History and Society. Cambridge: Cambridge University Press.

Chatterji, Joya. 2012 'South Asian Histories of Citizenship: 1946-1970.' The Historical Journal, 55: 1049-1071. http://journals.cambridge.org/abstract_S0018246X12000428

Chhotray, V. 2006. 'Justice at sea: Fishers' politics and marine conservation in coastal Odisha, India.' Maritime Studies 15

https://maritimestudiesjournal.springeropen.com/articles/10.1186/s40152-016-0043-3

Das, V. 2004. 'The signature of the state: the paradox of illegibility.' in Anthropology in the Margins of the State edited by Das, V. and Poole, D. 225-252. New Delhi: Oxford University Press.

Das, V. and Poole, D. 2004. 'State and its margins: Comparative ethnographies.' in Anthropology in the Margins of the State edited by Das, V. and Poole, D. 3-34. New Delhi: Oxford University Press.

Fearme, M.C. 2004. 'Deterritorialised citizenship and the resonance of the Sierra Leonean state.' in Anthropology in the Margins of the State edited by Das, V. and Poole, D. 81-116. New Delhi: Oxford University Press.

Ferguson, J. and Gupta, A. 2002. 'Spatialising states: Towards an ethnography of neoliberal governmentality'. American Ethnologist 29 (4): 981-1002 
Fuller, C. J., and Veronique Benei, eds., 2001. The Everyday State and Society in Modern India. London: Hurst and Company.

Gordillo, G, 2006. 'The Crucible of Citizenship: ID-paper Fetishism in the Argentinian Chaco.' American Ethnologist 33: 162-76.

Gupta, A. 2012. Red Tape: Bureaucracy, structural violence and poverty in India. Durham and London: Duke University Press.

Hansen, T. and Sepputat, F. 2005. 'Introduction.' in Sovereign bodies: Citizens, migrants and states in the post colonial world edited by Hansen, T. and Sepputat, F., 1-36. Princeton and Oxford: Princeton University Press.

Holston, H. 2008. Insurgent Citizenship: Disjunctions of democracy and modernity in Brazil. Princeton: Princeton University Press.

Isin, E.F. 2008. 'Theorising Acts of Citizenship.' in Acts of Citizenship, edited by E.F. Isin, and G.M. Nielsen, 15-43. London and New York: Zed Books.

Jayal, N.G. 2013. Citizenship and its Discontents: An Indian History. Massachusetts: Harvard University Press.

Kudaisya, Ganesh. 1997. 'Divided Landscapes, Fragmented Identities: East Bengal refugees and their rehabilitation in India, 1947-79.' Singapore Journal of Tropical Geography 17(1): 24-39.

McConnell, Fiona. 2011. 'Citizens and Refugees: Constructing and Negotiating Tibetan Identities in Exile.' Annals of the Association of American Geographers 103 (4): 967-983. http://dx.doi.org/10.1080/00045608.2011.628245

Mitchell, T. 1999. 'Society, Economy and the State Effect.' in State/Culture: State formation after the cultural turn edited by Steinmetz, G., 76-97. Ithaca, New York and London: Cornell University Press.

Rodrigues, Valerian. 2008. 'Citizenship and the Indian Constitution.' in Politics and Ethics of the Indian Constitution edited by Rajiv Bhargava, 164-188. New Delhi: Oxford University Press, New Delhi.

Sadiq, Kamal. 2009. Paper Citizens: How Illegal Immigrants Acquire Citizenship in Developing Countries. New York: Oxford University Press.

Kapur, Devesh. 2010. Diaspora, Development and Democracy: The Domestic Impact of International Migration from India. New Delhi: Oxford University Press.

Kapur, Ratna. 2012. Makeshift Migrants and Law: Gender, Belonging and Postcolonial Anxieties. London, New York and Delhi: Routledge. 


\footnotetext{
${ }^{1}$ These are not the real names of the villages.

${ }^{2}$ See also The Citizenship Act 1955. https://indiankanoon.org/doc/305990/ (Accessed 11 Nov 2016).

${ }^{3}$ See also The Citizenship Amendment Act. http://lawmin.nic.in/legislative/textofcentralacts/1985.pdf (Accessed 6 Jan 2016)

${ }^{4}$ Citizenship Amendment Act 2003. http://indiankanoon.org/doc/949775/ (Accessed 6 Jan 2016).

${ }^{5}$ http://mrunal.org/2013/10/land-reforms-post-independence-abolition-of-zamindari-reasons-impact-obstacleslimitations-first-amendment.html\#timeline (Accessed 2 October 2016)

${ }^{6}$ Ambagudia (2014) mentions an interesting detail that when refugees were brought to camps in Adivasi dominated western Odisha in the 1950s and 1960s, then the political decision was taken to classify them as Scheduled Castes. This worked as a means of 'political empowerment' as they were able to benefit from state reservation policies, even contesting elections on reserved seats. This in particular brought them into political conflict with the local adivasis. The social dynamics in coastal Odisha, where this study is sited, are different given the predominance of general castes.

${ }^{7}$ I interviewed an environmentalist-activist in Odisha in April 2012 who had filed such a court case, but I cannot be sure that it was this action that directly led to the High Court directive.

${ }^{8}$ The debate on citizenship has been reopened yet again more recently in the Indian Parliament.

http://indianexpress.com/article/india/india-news-india/joint-parliament-panel-discusses-citizenshipamendment-bill-3081157/
} 